\title{
Citizen Participation in City Governance: Experiences From Vietnam
}

\section{Authors: Thang V. Nguyen, Canh Q. Le, Bich T. Tran, Scott E. Bryant}

This is the peer reviewed version of the following article: Full citation, below, which has been published in final form at https://dx.doi.org/10.1002/pad.1702 This article may be used for noncommercial purposes in accordance With Wiley Terms and Conditions for self-archiving

Nguyen, Thang V., Canh Q. Le, Bich T. Tran, and Scott E. Bryant. "Citizen Participation in City Governance: Experiences From Vietnam." Public Administration and Development 35, no. 1 (February 2015): 34-35. DOI: https://dx.doi.org/10.1002/pad.1702.

Made available through Montana State University's $\underline{\text { ScholarWorks }}$ scholarworks. montana.edu 


\title{
Citizen Participation in City Governance: Experiences from Vietnam
}

\author{
THANG V. NGUYEN ${ }^{1}$, CANH Q. LE ${ }^{2}$, BICH T. TRAN ${ }^{2}$ AND SCOTT E. BRYANT ${ }^{3 *}$ \\ ${ }^{1}$ National Economics University, Vietnam and IPAG Business School (France) \\ ${ }^{2}$ National Economics University, Vietnam \\ ${ }^{3}$ Montana State University, USA
}

\begin{abstract}
SUMMARY
The radical political and economic reforms sweeping through former socialist countries during the last several decades have facilitated economic growth and urbanization. During this period of market reform and urbanization, citizen participation is greatly needed yet easily lost to other priorities. We employ stakeholder theory to examine whether citizen participation differs between large and small cities and between the poor and non-poor people in Vietnam. Using data from a sample of citizens in five centrally managed cities, we found that citizens in large cities and citizens that belong to "unofficially poor" groups participate less. For policy makers, this implies that citizen participation should be of central importance in the management of current cities' expansions. In addition, the categorization of "poor households" needs to be closely monitored to minimize the risk of de facto poor households being excluded from the group. Copyright (c) 2015 John Wiley \& Sons, Ltd.
\end{abstract}

KEY WORDS—citizen participation; governance; Vietnam; emerging economy

\section{INTRODUCTION}

Citizen participation has been widely recognized as important for improving government decision making (Baiocchi, 2003; Yang and Callahan, 2007; Mahjabeen et al., 2009). Public administration scholars and practitioners advocate citizen participation because of its potential to enhance governance or promote efficiency and redistribution (Baiocchi, 2003). However, promoting substantive participation has never been an easy task (Handley and Howell-Moroney, 2010). Public officials' and citizens' diverse interests, commitments, and expertise are the main obstacles for civic participation (Yang and Callahan, 2007).

Promoting authentic participation is particularly challenging in urban contexts because cities normally have populations that are more diverse and face more complex development problems than rural areas (Oliver, 2000). We ask whether city size has any effect on participation; previous studies have provided inconclusive results (Kelleher and Lowery, 2009). We also ask whether the poor have equal participation in public service as the non-poor. Consensus among researchers has been that the poor face more challenges to participating in government decision making (Mahjabeen et al., 2009; Gasparre, 2011). However, these studies have been conducted in countries where capitalist ideology is dominant and the poor may have never been a major participant in government.

In the context of transition economies, two questions remain pertinent. Does city size influence citizen participation? Do the poor participate less and have less access to public services than non-poor people? We employ stakeholder theory (Mitchell et al., 1997) and examine these two questions by studying five centrally managed cities in Vietnam.

Vietnam offers a unique natural laboratory as it is undergoing an extreme form of market liberation that operates in the presence of traditional socialist ideology (Painter, 2003). The country is an ideal setting for studying relationships between city size and citizen participation in the midst of rapid urbanization in which citizen participation is 
easily lost among other development priorities. The maintenance of a socialist form of government is also a unique feature that allows us to study whether the ideological role of the poor is sustained with the implementation of market liberation and urbanization. To our knowledge, systematic inquiries into these issues for transition economies are non-existent.

\section{THE CONTEXT OF VIETNAMESE URBANIZATION}

Since 1986, Vietnam has embarked on an economic reform that has produced radical changes in the country. These changes have been socioeconomic and, to some extent, political (Painter, 2003). Rapid urbanization has been one of the main factors that best embody this change (Albrecht et al., 2010).

In 2011, Vietnam's population was 87.8 million, with an annual growth rate of $1.37 \%$ during the period of 1990-2011. The growth of cities is a very recent phenomenon in the history of Vietnam (Albrecht et al., 2010). After the American/Vietnam War (1975-1986), the country faced extreme economic difficulty, and urban development was largely non-existent during that period. After the Doi moi policy (1986) was implemented, rapid economic growth has induced urbanization, and urban development has significantly increased during the last 15 years.

Since the mid-1990s, the urbanization process has occurred more rapidly. According to the Ministry of Construction, the number of urban units has increased from 629 in 1999 to 760 in 2012. A recent World Bank (WB) report estimated that Vietnam has an urbanization rate of 3.4\% per year, the highest in Southeast Asia (WB, 2011). By 2012, Vietnam had five centrally managed cities: Hanoi, Ho Chi Minh City, Da Nang, Can Tho, and Hai Phong. In addition, there were 60 cities that belonged to provinces. The proportion of urban dwellers rose from $19.5 \%$ in 1990 to almost $32 \%$ in 2011, with an annual growth rate of about $3.75 \%$ over the same period (GSO, 2011). The urban population increased 2.16 times in 21 years. Urban economies account for more than $70 \%$ of the national gross domestic product (GSO, 2011).

The rapid rate of urbanization in Vietnam has created a number of concerns about the sustainable development of cities in Vietnam. Media, political speeches, and researchers have recognized such pressing issues as poor urban planning, worsening environment, poor infrastructure, housing problems, unequal access to public services (e.g., education and health care), and high corruption, among others. The consensus has been that cities in Vietnam have grown faster than their governance capacity (Quertamp and de Miras, 2012).

Improving governance, including citizen participation in government, has been recognized as one of the major solutions for encouraging sustainable development in Vietnam (UNDP, 2012; WB, 2010, 2012). Whereas the term governance is new in Vietnam, citizen participation is not. Since the Revolution, in the past century, citizen participation has always been emphasized by the Party's leaders (e.g., Ho Chi Minh) and is always present in government policies. Recently, however, the country's market reform and economic growth have widened the gap between the rich and the poor and generated a number of interest groups (WB, 2012). This growth has three impacts on citizen participation. First, citizen participation is increasingly placed in competition with that of other groups (i.e., businesses and non-governmental organizations (NGOs)). Recently, interest groups and their influence on policymaking have been recognized as an important topic for research and policy agenda in Vietnam (WB, 2012). Secondly, the rapid urbanization rate has interfered with citizen governmental participation in cities. The larger the city, the more presence the interest groups assert. Thus, citizens' voices in cities may be diluted by the noise from other groups. Finally, the widening gap between the rich and the poor raises questions of whether these groups have similar voices in government decision making and what groups have a higher risk of being excluded. These questions are even more pertinent in the city context where the gap is larger than in rural areas.

\section{LITERATURE REVIEW}

\section{Citizen participation in local governance}

Scholars and practitioners have recognized the important role citizen participation plays in the decision-making process of governments (Baiocchi, 2003; Yang and Callahan, 2007; Mahjabeen et al., 2009). Citizen 
participation is considered fundamental to enhancing good governance, efficiency, and the fair distribution of wealth (Baiocchi, 2003). For citizens, participation increases the chance for individual voices to be heard. Participation can promote open-ended and public-minded discussions that may not originally be a part of the government officials' agendas (Baiocchi, 2003). Citizen participation facilitates government officials' accountability (Handley and Howell-Moroney, 2010), exerting either direct or indirect pressure on the officials to be accountable to participating groups. Finally, participation through networking and information sharing reduces the risk of groups being excluded or isolated (Small and Newman, 2001). For these reasons, participation in government provides opportunities to influence government for one's own benefit.

Citizen participation has been practiced in various settings. Most studies have examined cooperative participation, that is, citizens voicing their concerns in a cooperative manner with officials. These settings include participation in electoral voting (Verba et al., 1995), urban planning (Mahjabeen et al., 2009), budgeting and performance measurement (Berman and Wang, 2000; Ebdon, 2002), and community monitoring (Blair, 2000). Some studied settings were more confrontational in nature, such as sending complaints or denunciation letters to the government or joining groups to protest against certain government development programs (Holzner, 2007; Caren et al., 2011). The lack of opportunities for cooperative participation would induce more confrontational participation (Holzner, 2007). Participation can also take many different forms, with some being more interactive and substantive than others (Handley and Howell-Moroney, 2010). Public meetings, focus groups, simulations, committees, and surveys are among the most used methods to encourage cooperative participation (Berner, 2003).

However, encouraging substantive citizen participation is not an easy task (Baiocchi, 2003; Handley and Howell-Moroney, 2010). Baiocchi (2003) has noted that it may be too romantic to portray "virtuous citizens engaged in selfless discussions that may not reflect the conflict inherent in such exchange" (p. 52). On the one hand, government officials' negative attitude toward citizen participation has been identified as a major barrier to authentic participation. Facing competing demands, officials may fear that citizen involvement could increase conflict in the political system, increase problems with government policymaking (Yang, 2005), and decrease government agency effectiveness. Officials are also criticized for promoting their own agendas, as well as for their unwillingness to share power (Yang and Callahan, 2007). In addition, a lack of resources and overwhelming responsibilities can also be a source of fear for promoting citizen participation.

On the other hand, barriers for authentic participation come from citizens, as well. Citizens are often criticized for lacking competence, expertise, skills, and a commitment to participation. Those who frequently participate tend to promote their own agenda and thus are not necessarily representative of the entire community (Yang, 2005; Yang and Callahan, 2007; Mahjabeen et al., 2009).

These barriers suggest that participation opportunities are not equal for everybody. We turn to stakeholder theory for a conceptual framework to answer the following question: "who receives a better chance of participation?"

\section{Stakeholder theory and participation}

Government officials face competing demands from stakeholders, and they respond to these demands with different priorities (Saltzstein, 1992; Mitchell et al., 1997). Involvement decisions are based upon government officials' response to salient stakeholders who push for participation (Yang and Callahan, 2007). In this vein, citizens have to compete with other stakeholders, such as businesses and NGOs, to have their voices heard. Even among citizens, different groups of people may need to compete with each other should there be conflicting interests among them. In the end, the most salient stakeholders have the best chance to participate and influence the decision-making process (Mitchell et al., 1997).

According to the model of Mitchell et al. (1997), a stakeholder's salience depends on the stakeholder's possession of one or more relationship attributes: power, legitimacy, and urgency. Power refers to one's ability to bring about desired outcomes despite resistance. An actor's individual power is based on three types of resources: coercive power, based on the physical resources of force, violence, or restraints; utilitarian power, based on material or financial resources; and normative power, based on symbolic resources, such as prestige and esteem, love, or acquaintances. 
Legitimacy refers to the extent that an actor's structures and behaviors are socially accepted and expected (Meyer and Rowan, 1977; Scott, 1995). Aldrich and Fiol (1994) distinguished between cognitive legitimacy and sociopolitical legitimacy. Cognitive legitimacy refers to the extent the public knows about the stakeholder and his or her practices. Sociopolitical legitimacy refers to the extent to which a stakeholder conforms to recognized principles or accepted rules and standards. This legitimacy can be measured by how other stakeholders, the public, and government officials accept the individual and his or her practices as "appropriate and right given existing norms and laws" (Aldrich and Fiol, 1994, p. 648).

Urgency relates to the dynamics of stakeholder/government interactions. In the model of Mitchell et al. (1997), urgency refers to the extent that the stakeholder's claim is critical (criticality) and that government delay in attending to the claim or relationship is unacceptable to the stakeholder (time sensitivity).

Stakeholder theory sheds light into who has the opportunity to participate in government decision-making processes. Stakeholders who have more attributes (i.e., power, legitimacy, and urgency) and higher levels of the attributes would be more salient than those with fewer and lower levels of these attributes (Mitchell et al., 1997).

\section{HYPOTHESIS DEVELOPMENT}

\section{Participation in large cities}

Our first question is whether citizen participation differs between small and large cities. A number of studies suggested that citizens participate more in small cities because small communities promote more attachment and social capital (e.g., Barber, 1984; Oliver, 2000; Ross and Levine, 2001). Kelleher and Lowery (2009) labeled this preference as a "small-is-beautiful" perspective. On the other hand, several studies have demonstrated that larger cities have more utilities and activities to promote citizen participation (Lowery and Lyons, 1989; Lowery et al., 1992). This perspective was labeled as "big-is-lively" by Kelleher and Lowery (2009).

Stakeholder theory suggests that in large cities, citizens' relative salience would be lower than in small cities. First, citizens face stronger competition from other stakeholders in large cities than they do in small cities, which may weaken their power attributes. Large cities have a higher concentration of businesses, interest groups, NGOs, and so on. The number of actively involved citizens is also greater in large cities (Kelleher and Lowery, 2009). Thus, a citizen's participation in large cities is less likely to influence outcomes in local government decisions than it would in smaller cities.

In addition, an individual's social networks are difficult to establish and maintain in large cities (Yang and Callahan, 2007; Kelleher and Lowery, 2009). As cities develop, people's mobility is higher, disrupting community social networks. Social capital, strong ties, and social networks with local people and officials facilitate participation through increasing attachments to a particular community (Kelleher and Lowery, 2009). People prefer to interact with others who are like them because they share interests and are socialized with the same cultural norms (Costa and Kahn, 2003). Citizens face greater challenges in large cities for building such networks and have less strong social attachments, further hindering their power, relative to other stakeholders.

Second, citizens' concerns are less likely to be seen as legitimate and/or urgent in large cities compared with small cities. Dahl (1967) argued that larger communities are more likely to address larger urban development issues. These issues might include urban sprawl, infrastructure development, economic growth, and so on. By contrast, citizens are more attentive to local issues, such as affordable housing, well-paying jobs, and access to basic public services. Kelleher and Lowery (2009) found in their study that attention to these citizens' smaller interests diminishes in consolidated and concentrated metropolitan areas because these narrow concerns must share space on the policy agenda with broader issues. Thus, in the context of rapid urbanization, real attention to citizens' issues diminishes as we move from small cities to larger cities.

We expect these conclusions to hold true in a Vietnamese context. In Vietnam, powerful stakeholders (e.g., businesses, NGOs, and interest groups) are more concentrated in metropolitan areas (e.g., Hanoi and Ho Chi Minh City). The asymmetry of salience (power, legitimacy, and urgency) between these powerful groups and citizens is expected to be higher in large cities than in smaller cities. In addition, large cities are facing more complex urban development 
issues, such as overexpansion, poor infrastructure, pollution, and so on. Thus, citizens' daily concerns are being pushed to a lower priority in local governments' agendas. Therefore, we hypothesize the following:

H1: Citizen cooperative participation is weaker in large cities than in small cities.

\section{Participation from the poor}

Our next question is whether the poor have less participation in governance than non-poor people in Vietnamese cities. The poor are one of the disadvantaged groups in urban populations (Small and Newman, 2001; Baiocchi, 2003; Mahjabeen et al., 2009). Lack of participation from the poor has been recognized as one of the major obstacles to achieving inclusive development (Gasparre, 2011). Scholars have recognized that the poor often have low participation in governance (Blair, 2000; Small and Newman, 2001; Devas and Grant, 2003; Holzner, 2007; Mahjabeen et al., 2009). In several developing countries, governmental participation from the poor has experienced a declining trend as countries emphasize economic growth (Devas and Grant, 2003; Holzner, 2007).

We argue that the poor have lower salience than non-poor groups because of lower power, legitimacy, and urgency variables. First, the poor possess much less power than non-poor people. Their access to coercive power is limited, in part because of their low social capital (Coleman, 1988). For the poor, their disconnection with the employed and the wealthy makes them isolated (Small and Newman, 2001). This leads to their lack of information about opportunities to participate in civic life. In addition, the poor tend to socialize among themselves, creating additional unfavorable outsider opinions of the poor and further degrading the poor's willingness to participate in civic life.

One way for the poor to increase their coercive power is by promoting forces of violence and collective complaints. Most of the time, however, their violence is viewed as illegitimate. Collective complaints and violence are not encouraged in Vietnam. Thus, although violence and collective complaints might help increase the poor's power in some way, their legitimacy would be seriously eroded.

The poor, by definition, have much lower utilitarian power, which is based on material and financial resources. The free-market reform often widens the income gap between the rich and the poor, decreasing the poor's ability to participate in the civic structures in their communities (Holzner, 2007). Governments' emphasis on privatization, foreign direct investment, free trade, and poverty reduction through growth, rather than redistributive policies, may send signals to the poor that governments may not have their best interests in mind (Holzner, 2007). For many government officials, it is easier to access more visible elites than it is to engage the poor (Devas and Grant, 2003).

Secondly, the poor also suffer from legitimacy issues if they do try to participate in government. Too often, the poor are seen as beneficiaries of government and donor's actions (Mahjabeen et al., 2009; Gasparre, 2011), and their knowledge and skills are undervalued. The urban poor are sometimes even seen as trouble-making groups (Baiocchi, 2003).

Finally, the urgency of the poor's issues may be marginalized when compared with a country's other development priorities. For countries that emphasize market reform and growth, such issues as privatization, promotion of entrepreneurs, and promotion of investment may be given higher priority (Holzner, 2007). This is even more apparent in rapidly urbanized areas where issues such as investment and infrastructure development account for a large proportion of the policy agenda.

The previous theoretical discussion suggests that the poor have lower cooperative and higher confrontational participation (and voices) in governments' decision-making processes. The context of Vietnam, however, provides conflicting arguments on this issue. On the one hand, the Doi moi policy has promoted economic growth and widened the gap between the rich and the poor. Thus, the urban poor are expected to have less power than non-poor people. Similarly, the poor in Vietnam are expected to have lower social capital and weaker local social networks than non-poor people. This reduces their legitimacy because in the absence of strong institutions, social networks are usually effective ways to improve legitimacy (Le et al., 2006; Le and Nguyen, 2009). Thus, this trend supports the argument that the poor in Vietnam are less salient than non-poor people. 
On the other hand, Vietnam's socialist ideology is primarily pro-poor. This ideology is reflected in a number of government policies toward poor households. According to current policies, local governments use their official poverty line to identify poor households. If a household is assessed by commune officials and is found to be a household living below the local poverty line, they will be given a poor household book that certifies their poverty status. With poor household books, people can access a number of government support programs such as free health insurance, subsidized government loans, house construction subsidies, and so on. The poor's voices are listened to and their needs are addressed by officials, as required by government policies. People with poor household books receive focused attention through many social campaigns for the poor. The poor household books significantly increase the poor's salience. Thus, those with poor household books (officially poor households) would have more salience, and we would expect them to be participating in civic life more than non-poor people.

However, poverty identification is a complicated process. It includes income surveys, assessments of local authorities, and the agreement of other households and mass organizations (MOLISA, 2012). This process is highly political because many households want to be on the list in order to receive government support. By contrast, local officials feel pressure to lower reported poverty rates, as they are a measure of their performance. A recent study suggested that there could be a large difference between the poverty status of a household recognized by local authorities and the poverty status indicated by more objective measures (Nguyen and Tran, 2014). In other words, many households have low incomes but do not have poor household books. These include families who live just above the poverty level or who are not assessed or identified as poor households. Official statistics from the Ministry of Labor, Invalids, and Social Affairs showed that in 2011, there are about 2.58 million poor households (with the books) and 1.52 million near-poor households, where near poor is defined as those whose income is within 1.5 times the poverty level. Because the poverty line in Vietnam is just about $50 \%$ of the WB's poverty line, these numbers do not fully capture the number of low-income families. We group near-poor and unrecognized poor families as unofficially poor households.

The officially poor receive much more consideration and support from the government. They are motivated to participate cooperatively with the government. Conversely, the unofficially poor are not the focal point of policy attention and yet have all the same characteristics as the poor in the international studies we have discussed. They had low motivation and opportunities to participate cooperatively with local officials. As a result, they are more likely to engage in confrontational interactions with the government. Therefore, in the context of urban Vietnam, we hypothesize the following:

H2: Officially poor people participate in a cooperative manner more than non-poor people.

H3a: Unofficially poor people participate less in a cooperative manner than non-poor people.

$H 3 b$ : Unofficially poor people participate in a more confrontational manner than non-poor people.

H4: Unofficially poor people have less access to quality public services than non-poor people.

\section{METHODS}

\section{Data}

Our key data come from the 2011 UNDP survey, "The Vietnam provincial governance and public administration performance index (PAPI): Measuring citizen's experiences." Using citizens' experiences and assessments based on their interaction with governmental authorities at different levels, PAPI measures the standards of government and public administration. PAPI focuses on six different dimensions of provincial governance and public administration, including participation of local citizens, transparency, accountability, corruption control, public administration procedures, and public service delivery in the policy cycle. In 2011, the PAPI survey was conducted in all 63 provinces of Vietnam, with a total sample size of 13642 randomly selected citizens.

The goal of the PAPI sampling strategy was to ensure that comparisons of PAPI results would be fair across all provinces. A multistage sampling strategy was adopted. At the first stage, the district that serves as the 
provincial capital was intentionally selected. Two other districts were then sampled using the probability proportional to size method. This strategy was repeated when selecting two communes for each selected district and two villages for each commune. It should be noted that among 63 provinces of Vietnam, the six largest provinces have double the number of selected districts. In the final stage, households and respondents were randomly selected from the list of households and household members. Face-to-face interviews were employed to collect the data. A detailed interview manual was developed to assist the interview process. Interviewers were carefully selected and trained to ensure accuracy and consistency in data collection. In addition, multiple layers (national, provincial, and team levels) of monitoring and quality assurance were applied (see UNDP, 2012, for more details on methodology).

In our research, we focused on the citizen participation in five centrally managed cities in Vietnam: Hanoi, Ho Chi Minh City, Da Nang, Hai Phong, and Can Tho. The PAPI 2011 survey had 1700 respondents from 21 districts of these five cities. To supplement the PAPI data, we also collected districts' data, such as average land price and number of public service points. These supplement data came from cities' and districts' websites.

\section{Measurement}

\section{Officially poor and unofficially poor households}

Our study measures officially poor and unofficially poor households by considering two questions from the PAPI survey, which captures the economic situation of the respondent's household:

- Officially poor households are those with poor household books, granted by the government. This is a binary variable with 1 as officially poor and 0 as otherwise.

- Unofficially poor households are those who assessed themselves as poor but did not have poor household books. The household self-assessment of their economic status was validated with a number of basic facilities they had in their house at the time of survey. This is a binary variable with 1 as unofficially poor and 0 as otherwise.

City size

In 2011, Hanoi and Ho Chi Minh cities had urban populations of about 2.89 and 6.25 million people, respectively (GSO, 2011). The populations of the other three cities were less than one million. We therefore categorize Hanoi and Ho Chi Minh City as large cities. Can Tho, Da Nang, and Hai Phong belong to the small-city group.

\section{Citizen participation}

Officially poor groups, by law, were beneficiaries of a number of government support programs, including tuition waivers, free health care, or subsidized loans. We excluded participation in these government programs and only examined participation settings that were not directly associated with government poverty reduction programs. We adapted Wang's (2001) concept of participation to include several kinds of participation: voting, cooperative participation, and confrontational participation in city management. Participation of citizens was measured by looking at four aspects available in the PAPI data:

- Invitation to vote: The first aspect relates to whether a household received an invitation to vote in local elections. Before an election, the government had a mass communication campaign to persuade people to vote. In addition, local officials would visit and/or send invitations to individual households. This process was independent of the process of poverty identification. Receiving an invitation reflects whether a household was excluded from the officials' attention. Voting invitation is a binary variable that equals 1 if an individual is invited to vote at elections of local people-voted positions, and 0 otherwise.

- Voting: Participation in voting was measured by whether a person actually voted in the latest local election. Voting is a binary variable that equals 1 if an individual voted in the latest election, and 0 otherwise.

- Cooperative participation in management issues: Cooperative participation in management issues was measured by considering whether the respondent contributed any resources for city development, gave opinions on designing and developing construction projects, contributed opinions on local development plans, or provided any opinion on local government performance. This binary variable has a value of 1 if the respondent did any one of those activities, and 0 otherwise. 
- Confrontational participation in management issues: Confrontational participation was measured by considering whether the respondent sent any complaint or denunciation letters to the government, attended any protest meetings, or joined any collective petitions. This binary variable has a value of 1 if the respondent did any one of those activities, and 0 otherwise.

Access to basic public services

Another dependent variable was citizens' access to three basic public services: waste collection, clean water supply, and safety. There are no specific policies that directly subsidize officially poor households for these services. Therefore, actual access to these services better reflects if the poor groups are disadvantaged by not receiving these services.

- Waste collection service: We created a binary variable that equals 1 if households have access to garbage collection service in their community, and 0 otherwise.

- Clean water service: Access to clean water service was measured if households used pipe-supplied water or a centrally supplied water station. A binary variable was created for this measure.

- Safety: To measure a person's level of perceived public protection/safe feeling, this study asked "Do you feel safe in your locality?" This proxied binary variable was 1 if the respondent felt safe, and 0 otherwise.

\section{Control variables}

At the individual level, we controlled for age, gender, education, membership and leadership of sociopolitical organizations, work sector, and whether the respondent was the household head. These data came from the PAPI

Table 1. Marginal effect on citizen participation

\begin{tabular}{|c|c|c|c|c|}
\hline & $\begin{array}{l}\text { Invitation } \\
\text { to vote }\end{array}$ & Voting & $\begin{array}{l}\text { Cooperative } \\
\text { participation }\end{array}$ & $\begin{array}{l}\text { Confrontational } \\
\text { participation }\end{array}$ \\
\hline Female $^{+}$ & -0.0140 & -0.0346 & $-0.0462 *$ & 0.0007 \\
\hline Age & $0.0036^{* * *}$ & $0.0061^{* * *}$ & $0.0040 * * *$ & 0.0003 \\
\hline Urban districts $^{+}$ & $-0.2992 * * *$ & $-0.1677 * * *$ & $-0.0915^{* *}$ & -0.0011 \\
\hline Primary school ${ }^{+}$ & 0.0554 & $0.3054^{* *}$ & $0.3393 * * *$ & 0.7826 \\
\hline Secondary school ${ }^{+}$ & $0.1738^{*}$ & $0.3873 * * *$ & $0.3887 * * *$ & 0.5363 \\
\hline Tertiary school $^{+}$ & $0.2299 * *$ & $0.4017 * * *$ & $0.4549 * * *$ & 0.5371 \\
\hline Graduate $^{+}$ & $0.2015^{* *}$ & $0.4115^{* * *}$ & $0.4566^{* * *}$ & 0.6597 \\
\hline Post-graduate $^{+}$ & 0.1562 & $0.5331 * * *$ & $0.3954 * * *$ & Omitted \\
\hline Members of social associations ${ }^{+}$ & $0.1467 * * *$ & $0.1668 * * *$ & $0.1612 * * *$ & 0.0080 \\
\hline Work in private production area ${ }^{+}$ & 0.0046 & 0.0305 & 0.0021 & 0.0091 \\
\hline Work in state production rea $^{+}$ & -0.0219 & 0.0109 & -0.0398 & 0.0096 \\
\hline Work in state agencies ${ }^{+}$ & -0.0132 & 0.0295 & 0.0656 & 0.0078 \\
\hline Work in police and military ${ }^{+}$ & -0.0083 & -0.0001 & $0.1583 * *$ & -0.0018 \\
\hline Household head $^{+}$ & $0.0591 * *$ & $0.1628 * * *$ & $0.0473 *$ & 0.0052 \\
\hline Leaders of sociopolitical organization ${ }^{+}$ & 0.0680 & 0.0043 & $0.2529 * * *$ & 0.0022 \\
\hline Officially poor $^{+}$ & 0.0661 & $0.1345 * * *$ & 0.0051 & -0.0083 \\
\hline Unofficially poor ${ }^{+}$ & $-0.1259 * *$ & $-0.1060 * *$ & 0.0026 & $0.0282 * *$ \\
\hline Big cities ${ }^{+}$ & $-0.3802^{* * *}$ & $-0.2621 * * *$ & $-0.0842 * *$ & -0.0078 \\
\hline No. of public administrative service agents & $0.0227 * * *$ & $0.0133 * * *$ & -0.0012 & -0.0001 \\
\hline Average land prices per square meter & $0.0021 *$ & 0.0005 & -0.0002 & -0.0001 \\
\hline Observations & 1700 & 1700 & 1700 & 1684 \\
\hline Pseudo- $R^{2}$ & 0.2055 & 0.1492 & 0.0946 & 0.0918 \\
\hline$Y$ (dependent variable) & 0.6375 & 0.3713 & 0.5219 & 0.1241 \\
\hline
\end{tabular}

${ }^{+} \mathrm{d} y / \mathrm{d} x$ is for discrete change of dummy variable from 0 to 1 .

*Significant at the $10 \%$ level.

$* *$ Significant at the $5 \%$ level.

$* * *$ Significant at the $1 \%$ level. 
survey. At the district level, we controlled for number of public administration service provision units, average land price, and whether the district is urban or rural. These data came from city's and district's websites.

\section{EMPIRICAL RESULTS}

\section{Sample's statistics}

In our sample of 1700 observations, the official poor and the unofficially poor account for $10.1 \%$ and $7.4 \%$, respectively. In the sample, $63.8 \%$ of respondents were invited to vote in any local elections, $42 \%$ voted in the latest election, $60.9 \%$ of the respondents cooperatively participated in management activities via contributing resources or giving opinions and ideas to the local government, and $2.2 \%$ of the respondents engaged in some confrontational participation activities.

\section{Hypothesis testing}

\section{Citizen participation}

We ran separated multivariate probit models for four measures of citizen participation: invitation to vote, electoral voting, cooperative participation, and confrontational participation. The results of marginal effect after probit are presented in Table 1 .

Table 2. Marginal effect of citizens' access to basic public services

\begin{tabular}{|c|c|c|c|}
\hline & $\begin{array}{l}\text { Waste collection } \\
\text { service }\end{array}$ & $\begin{array}{l}\text { Clean water } \\
\text { service }\end{array}$ & Safety \\
\hline Female $^{+}$ & 0.009 & -0.002 & -0.005 \\
\hline Age & $0.001 * *$ & $0.209 * * *$ & -0.015 \\
\hline Urban districts $^{+}$ & $0.105 * * *$ & $0.002 * * *$ & 0.000 \\
\hline Primary school ${ }^{+}$ & $0.020 * * *$ & 0.013 & -0.029 \\
\hline Secondary school $^{+}$ & $0.042 * * *$ & $0.037 *$ & -0.110 \\
\hline Tertiary school $^{+}$ & $0.064 * * *$ & $0.051 * *$ & -0.126 \\
\hline Graduate $^{+}$ & $0.033 * * *$ & $0.051 * * *$ & $-0.222 *$ \\
\hline Post-graduate $^{+}$ & Omitted $^{++}$ & -0.007 & $-0.419 * *$ \\
\hline Members of social associations ${ }^{+}$ & -0.001 & 0.008 & 0.003 \\
\hline Work in a private production area ${ }^{+}$ & -0.005 & 0.007 & 0.010 \\
\hline Work in a state production area $^{+}$ & $0.018 * * *$ & $0.044 * * *$ & 0.013 \\
\hline Work in state agencies ${ }^{+}$ & 0.010 & $0.034 * * *$ & $0.044 *$ \\
\hline Work in police and military ${ }^{+}$ & Omitted $^{+++}$ & $0.039 * * *$ & $0.070 * *$ \\
\hline Household head $^{+}$ & 0.004 & -0.001 & -0.003 \\
\hline Leaders of sociopolitical organizations $^{+}$ & -0.013 & -0.031 & 0.002 \\
\hline Officially poor $^{+}$ & -0.002 & $-0.038 * *$ & 0.014 \\
\hline Unofficially poor $^{+}$ & $-0.032 *$ & -0.027 & $-0.067 *$ \\
\hline Metropolitans $^{+}$ & $0.133 * * *$ & $-0.030 * * *$ & $-0.071 * * *$ \\
\hline No. of public administrative service agents & $-0.001 * * *$ & -0.001 & 0.002 \\
\hline Average land prices per square meter & 0.001 & $0.006 * * *$ & $0.002 * * *$ \\
\hline Pseudo- $R^{2}$ & 0.4137 & 0.4607 & 0.0357 \\
\hline$p$ (dependent variable) & 0.9832 & 0.9614 & 0.8830 \\
\hline Observations & 1626 & 1700 & 1700 \\
\hline
\end{tabular}

${ }^{+} \mathrm{d} y / \mathrm{d} x$ is for discrete change of dummy variable from 0 to 1 .

${ }^{++}$This has been omitted because "Post-graduate $=0$ " predicts success perfectly; 16 observations were not used.

${ }^{+++}$This has been omitted because "Work in police and military $=0$ " predicts success perfectly; 58 observations were not used. *Significant at the $10 \%$ level.

**Significant at the 5\% level.

$* * *$ Significant at the $1 \%$ level. 
Citizens in large cities participated less than those in small cities in all three measures: invitation to vote, voting in the last election, and cooperative participation in management issues $(p<0.001)$, strongly supporting H1. The marginal effects of the officially poor on participation are all positive, but significant only for voting $(p<0.001)$. This result partially supports $\mathrm{H} 2$. The estimated results also show that unofficially poor households were less likely to be invited to vote $(p<0.01)$ and participated less in electoral voting $(p<0.01)$ than non-poor households, supporting H3a. By contrast, unofficially poor households were more likely to engage in confrontational interactions with government $(p<0.01)$, supporting $\mathrm{H} 3 \mathrm{~b}$.

Access to public services

Table 2 summarizes probit results related to people's access to three basic public services: waste collection, clean water, and safety. Unofficially poor people have less access to waste collection services and perceive less safety $(p<0.05)$, supporting $\mathrm{H} 4$.

\section{DISCUSSION}

The aim of our paper is to explore whether citizen participation in governance differs between large and small cities and between poor and non-poor citizen groups. We draw on stakeholder theory to develop hypotheses and gather survey data from a sample of citizens in five centrally managed cities of Vietnam to test these hypotheses.

Our study's results strongly supported our hypothesis that, in the context of a high urbanization rate in Vietnam, citizen participation is weaker in large cities than in small cities. Results related to citizen participation and the poor's access to public services were mixed. On the one hand, officially poor families, those with poor household books, appeared to participate more than non-poor people. Their access to public services was not significantly lower than that of non-poor people. On the other hand, unofficially poor people participated less in electoral voting, engaged more in confrontational activities with the government, and had less access to basic public services than non-poor people. This mixed result reflects complex interactions between the traditional pro-poor socialist ideology and current pro-growth market reform (Painter, 2003).

At the outset, we want to acknowledge this study's limitations. The unofficially poor group was identified mostly on the basis of the respondent's self-report. Although our reliability check suggested that the respondent's self-report was acceptable, future studies may want to use objective household income data to verify our results. Secondly, with a cross-sectional design, our results demonstrated associations, not causal relationships. Nevertheless, we believe our study has merit as it relied on one of the most comprehensive and rigorous citizen surveys of the country.

\section{Theoretical implications}

Our study suggests that stakeholder theory (Mitchell et al., 1997) is a useful framework for analyzing citizen participation. In the context of developing countries, such as Vietnam, this theory appears to be very appropriate for analyzing the relative salience of different stakeholders. We believe a dynamic approach to the theory is also possible where researchers can track the changes of citizens' salience at different stages of city development.

Our study contributes to the debate on the effect of city size on citizen participation. Our results suggest that under a rapid urbanization process where economic growth, city sprawl, and investment promotion are of high priority, citizens in larger cities would participate less than those in smaller cities. Future research could explore if a country's market reform and/or economic growth moderates the effect of city size on citizen participation.

Our study supports the argument that the poor are in a disadvantaged position for participation and they need assistance from government or other organizations in order to make their voices heard (Small and Newman, 2001; Holzner, 2007; Mahjabeen et al., 2009). However, where criteria and processes to define who constitute the poor are primarily subjective, government support may not be given to the right people. Future research could examine how the formation of target groups influences the risk of one being excluded from governmental decision making. 


\section{Implications for public policies}

Those developing urbanization policies in Vietnam need to pay attention to creating and sustaining citizen participation. This is especially important for large cities. With their high rates of economic growth and urbanization, large cities in Vietnam are facing tremendous pressure on city expansion, investment, infrastructure development, pollution control, and social stability. Local governments in these cities need more support and participation from their citizens. Ironically, citizens in these large cities are less likely to participate in governmental decision making. For sustainable development, governments of large cities need to better balance between mobilizing investment and business involvement with encouraging citizen engagement. For small and growing cities, our study suggests that while promoting investment and expansion, cities should also seriously consider their citizens' participation. Without strong citizen engagement, the rapid growth of cities will likely bring social problems.

Another important issue for public policy is the potential exclusion of unofficially poor people in civic life. The Vietnamese government has paid considerable attention to support the poor with various attention and subsidies. However, families who just escape the poverty line or those who are missed in the government's assessment of poor families have a very high risk of being excluded. As a result, this group may be more inclined to use a confrontational approach, such as joining protests or signing collective petitions. Those managing programs to support the poor should seriously consider this phenomenon. City governments need to closely monitor poor households at the local level to ensure that truly poor households are not mistakenly excluded from civic participation.

Citizen participation was a critical success factor for Vietnam's cultural revolution in the 20th century and has never been absent in the Party's ideology. It is even more pertinent to recognize the country's ambition for industrialization and modernization through market reform. Yet, market liberation and rapid urbanization have somehow downgraded citizen participation. In this process, unofficially poor people are at the highest risk for being excluded from participating in governance. Much like other transitional countries, Vietnam is struggling to find a balance between promoting growth and sustaining equality. In this respect, the experience of Vietnam can be of value to other countries.

\section{ACKNOWLEDGEMENTS}

We gratefully acknowledge financial support from UNDP Vietnam. We would like to thank Jairo Acuña-Alfaro and Do Thi Thanh Huyen (UNDP Vietnam), Edmund Malesky (Duke University), and participants of UNDP's Thematic Quantitative Policy Research on Governance and Public Administration in Viet Nam (2012) for their helpful comments and suggestions. We are responsible for any remaining errors and omissions.

\section{REFERENCES}

Albrecht D, Hocquard H, Papin P. 2010. Urban development in Vietnam: the rise of local authorities resources, limits, and evolution of local governance. Focales Report \#5. Agence Française de Développement.

Aldrich H, Fiol M. 1994. Fools rush in? The institutional context of industry creation. Academy of Management Review 19(4): 645-670.

Baiocchi G. 2003. Emerging public spheres: talking politics in participatory governance. American Sociological Review 68(1): 52-74.

Barber B. 1984. Strong Democracy. University of California Press: Berkley, CA.

Berman E, Wang X. 2000. Performance measurement in U.S. counties. Public Administration Review 60(5): 409-420.

Berner M. 2003. Current practices for involving citizens in local government budgeting: moving beyond method. Public Administration Quarterly 27(3/4): 410-432.

Blair H. 2000. Participation and accountability at the periphery: democratic local governance in six countries. World Development 28(1): 21-39.

Caren N, Ghoshal R, Ribas V. 2011. A social movement generation: cohort and period trends in protest attendance and petition signing. American Sociological Review 76(1): 125-151.

Coleman JS. 1988. Social capital in the creation of human capital. American Journal of Sociology 94: S95-S120.

Costa LD, Kahn EM. 2003. Civic engagement and community heterogeneity: an economist's perspective. Perspectives on Politics 1: 103-112.

Dahl R. 1967. The city in the future of democracy. American Political Science Review 61: 953-970.

Devas N, Grant U. 2003. Local government decision-making - citizen participation and local accountability: some evidence from Kenya and Uganda. Public Administration and Development 23: 307-316.

Ebdon C. 2002. Beyond the public hearing: citizen participation in the local government budget process. Journal of Public Budgeting, Accounting, and Financial Management 14(2): 273-294. 
Gasparre A. 2011. Emerging network of organized urban poor: restructuring the engagement with government toward the inclusion of the excluded. VOLUNTAS: International Journal of Voluntary and Nonprofit Organizations 22: 779-810.

General Statistics Office or Vietnam (GSO). 2011. National statistics. Available at: http://www.gso.gov.vn. [Accessed on November 1, 2013].

Handley MD, Howell-Moroney M. 2010. Ordering stakeholder relationships and citizen participation: evidence from the Community Development Blocks Grant Program. Public Administration Review 70(4): 601-609.

Holzner AC. 2007. The poverty of democracy: neoliberal reforms and political participation of the poor in Mexico. Latin American Politics and Society 49(2): 87-122.

Kelleher AC, Lowery D. 2009. Central city size, metropolitan institutions and political participation. British Journal of Political Science 39: 59-92.

Le TBN, Nguyen VT. 2009. The impact of networking on bank financing: the case of Vietnamese small and medium-sized enterprises. Entrepreneurship: Theory and Practice 33(4): 867-887.

Le TBN, Venkatesh S, Nguyen VT. 2006. Getting bank financing: study of Vietnamese private firms. Asia Pacific Journal of Management 23(2): 209-227.

Lowery D, Lyons EW, DeHood HR. 1992. Institutionally induced attribution errors: their composition and impact on citizen satisfaction with local government services. American Politics Quarterly 18: 169-196.

Lowery D, Lyons EW. 1989. The impact of jurisdictional boundaries: an individual-level test of the Tiebout model. Journal of Politics 51: 73-79.

Mahjabeen Z, Shrestha KK, Dee AJ. 2009. Rethinking community participation in urban planning: the role of disadvantaged groups in Sydney metropolitan strategy. Australian Journal of Regional Studies 15(1): 45-63.

Meyer J, Rowan B. 1977. Institutionalized organizations: formal structure as myth and ceremony. American Journal of Sociology 83(2): 340-363.

Mitchell KR, Agle RB, Wood JD. 1997. Toward a theory of stakeholder identification and salience: defining the principle of who and what really counts. Academy of Management Review 22(4): 853-886.

MOLISA. 2012. Circular 21 (05/09/2012): Instructions to Annual Survey, Review, and Identification of the Poor and Near-poor Households. Ministry of Labor, Invalids, and Social Affairs: Hanoi.

Nguyen VT. 2005. Learning to trust: a study of interfirm trust dynamics in Vietnam. Journal of World Business 40(2): $203-221$.

Nguyen VC, Tran A. 2014. Poverty identification: practice and policy implications in Vietnam. Asian-Pacific Economic Literature 28(1): $116-136$.

Oliver JE. 2000. City size and civic involvement in metropolitan America. American Political Science Review 94: 361-373.

Painter M. 2003. Public administration reform in Vietnam: problems and prospects. Public Administration and Development 23(3): 259-271.

Quertamp F, de Miras C. 2012. Periurbanization and governance of large metropolises in Vietnam. In Trends of Urbanization and Suburbanization in Southeast Asia, Tran TNQ, Quertamp F, de Miras C, Nguyen QV, Le VN, Truong HT (eds). Ho Chi Minh City General Publishing House: Ho Chi Minh City; 75-92.

Ross BH, Levine MA. 2001. Urban Politics: Power in Metropolitan America. F.E. Peacock Publishers, Inc.: Itasca, IL.

Saltzstein HG. 1992. Bureaucratic responsiveness: conceptual issues and current research. Journal of Public Administration Research and Theory 2 (1): $63-88$.

Scott WR. 1995. Institutions and Organizations. Sage: Thousand Oaks, CA.

Small LM, Newman K. 2001. Urban poverty after the truly disadvantaged: the discovery of the family, the neighborhood, and culture. Annual Review of Sociology 27: 23-45.

UNDP. 2012. The Vietnam Provincial Governance and Public Administration Performance Index (PAPI) 2011: MEASURING CITIZEN EXPERIENCE. United Nations Development Programme: Hanoi.

Verba S, Schlozman K, Brady H. 1995. Voice and Equality. Harvard University Press: Cambridge, MA.

Wang X. 2001. Assessing public participation in U.S. cities. Public Performance \& Management Review 24(4): 322-336.

WB. 2010. Vietnam Development Report 2010-Modern Institution. World Bank: Hanoi.

WB. 2011. Danh gia do thi hoa o Viet Nam. World Bank: Hanoi.

WB. 2012. Corruption from the Perspectives of Citizens, Firms, and Public Officials: Results of Sociological Surveys. World Bank: Hanoi.

Yang K. 2005. Public administrators' trust in citizens: a missing link in citizen involvement efforts. Public Administration Review 65(3): 273-285.

Yang K, Callahan K. 2007. Citizen involvement efforts and bureaucratic responsiveness: participatory values, stakeholder pressures, and administrative practicality. Public Administration Review 67(2): 249-264. 